Jurnal Mahasiswa BK An-Nur : Berbeda, Bermakna, Mulia

Volume 7 Nomor 2 Tahun 2021

Tersedia Online: https://ojs.uniska-bjm.ac.id/index.php/AN-NUR

p-ISSN. 2460-9722 | e-ISSN. 2622-8297

\title{
UPAYA PELAYANAN BIMBINGAN KARIR TERHADAP SISWA MAN 2 LAMONGAN SELAMA PANDEMI COVID-19
}

\author{
Farda Muslimah ${ }^{1}$, Imro’atul Hayyu Erfantini ${ }^{2}$ \\ ${ }^{1}$ Mahasiswa Jurusan Tadris Bahasa Inggris, UIN Maulana Malik Ibrahim Malang, \\ ${ }^{2}$ Dosen Jurusan Pendidikan Islam Anak Usia Dini, UIN Maulana Malik Ibrahim Malang \\ Email: ${ }^{1}$ fardamuslimah288@gmail.com, ${ }^{2}$ hayyu.erfantinni@uin-malng.ac.id
}

\begin{abstract}
Abstrak
Seperti yang kita ketahui bahwa bahwa Indonesia masih berada dalam proses berperang melawan wabah COVID-19. Hal tersebut mempengaruhi aspek pendidikan di Indonesia dengan diberlakukannya sekolah daring, kemudian dengan adanya kebijakan tersebut menyebaBimbingan dan Konselingan pelayanan Bimbingan dan Konseling juga dilakukan secara daring. Bimbingan karir merupakan salah satu bimbingan menyeluruh yang sangat urgent ungtuk diberikan kepada siswa. Sedangkan dalam pembelajaran daring banyak sekali potensi adanya hambatan yang dialami baik siswa maupun guru BK Tujuan penelitian ini untuk mengetahui upaya bimbingan karir yang dilakukan oleh guru BK terhadap siswa MAN 2 Lamongan selama masa pandemic COVID-19. Penelitian dilakukan dengan pendekatan Kualitatif deskriptif dengan Metode penelitian Study Kasus. Hasil penelitian dari Bimbinagn dan Konseling selama Pandemi yakni upaya yang dilakukan oleh guru Bimbigan dan Konseling yakni dengan menyelenggarakan Sosialisasi Masuk perguuan tinggi, CCD (Career and College Day), pembuatan grup WhatsAps masuk Perguruan Tinggi, Pelayanan Konsultasi offline, dan pemyebaran informasi Lowongan Kerja melalui Grup WhatsAps. Kendala yang dihadapi adalah Sinyal dan media yang tidak memadahi, Tidak terjadi komunikasi yang sempurna antara Siswa dan Guru Bimbingan Konseling, dan keterbatasan kesempatan guru BK saat konsultasi online.
\end{abstract}

Kata Kunci: Pelayanan; Bimbingan karir; Pandemi COVID-19

\begin{abstract}
As we know that Indonesia is still in the process of fighting the COVID-19 outbreak. This affected in Indonesian education aspects with the implementation of online schools, then with the existence of this policy Guidance and Counseling services are also carried out online. Career guidance is one of the most urgent comprehensive guidance to be given to students. Meanwhile, in online learning, there are many potential obstacles experienced by both students and teachers. The purpose of this study was to find out the career guidance efforts carried out by teachers for MAN 2 Lamongan students during the COVID-19 pandemic. The research was conducted with a descriptive qualitative approach with a case study research method. The results of the research from Guidance and Counseling during the Pandemic are the efforts made by Guidance and Counseling teachers, namely by organizing College Admission Socialization, CCD (Carrier and College Day), creating WhatsAps groups to enter Higher Education, offline Consulting Services, and dissemination of job vacancies information through WhatsAps Group. The Obstacles are inadequate signals and media, imperfect communication between students and counseling guidance teachers, and limited opportunities for guidance and counseling teachers during online consultations.
\end{abstract}

Keywords: Service; Career guidance; COVID-19 Pandemic

Dipublikasikan Oleh :

UPT Publikasi dan Pengelolaan Jurnal

Universitas Islam Kalimantan Muhammad Arsyad Al-Banjari Banjarmasin 


\section{Farda Muslimah $^{1}$, Imro'atul Hayyu Erfantini ${ }^{2}$ \\ Jurnal Mahasiswa BK An-Nur : Berbeda, Bermakna, Mulia \\ Volume 7 Nomor 2 Tahun 2021 \\ Tersedia Online: https://ojs.uniska-bjm.ac.id/index.php/AN-NUR \\ p-ISSN. 2460-9722 | e-ISSN. 2622-8297}

\section{PENDAHULUAN}

Dalam lingkungan pendidikan baik dalam Sekolah maupun Universitas didalamnya selalu memiliki komponen Bimbingan dan Konseling. Bimbingan dan Konseling memiliki dua kata yang berkesinambungan, yakni Bimbingan dan Konseling memiliki satu makna yaitu memberikan pedoman atau bantuan. Namun beberapa pendapat mengartikan Bimbingan dan Konseling memiliki arti yang berbeda. Bimbingan dalam Bhs Inggris 'Guidance' yang memiliki arti menunjukkan, bimbingan dapat diartikan kedalam hal yang sangat terkait dengan proses pembelajaran di sekolah. Kemudian konseling diartikan sebagai upaya pemberian atau pendambingan kepada seseorang yang memiliki gangguan psikis. Sehingga dapat disimpulkan bahwa Bimbingan dan Konseling adalah kegiatan pemberian arahan, pedoman atau bantuan yang diberikan oleh konselor (guru Bimbingan dan Konseling) kepada konseli (siswa). Kegiatan tersebut dilakukan dengan sistematika guru Bimbingan dan Koseling memberikan saran pemecarhan masalah kepada siswa, namun disini yang bertindak sebagai pemilik keputusan tetap pada siswa itu sendiri. Layanan bimbingan konseling dapat dilaksanakan secara langsung tatap muka ataupun melalui media. Layan Bimbingan dan Konseling memiliki sifat sistematis dan berkelanjutan menurut Hermawan dkk (2019). Adaya bimbingan konseling dalam sebuah lembaga pendidikan diharapkan untuk membantu siswa agar dapat menjadi individu yang berguna bagi sekitarnya, memiliki wawasan dan dapat beradaptasi dengan lingkungannya. Serta dapat menjadi pribadi yang matang dan mandiri dalam kehidupannya. Kemudian selanjutnya individu diharapkan dapat mengemban tugas-tugas perkembangan selama hidupnya dengan secara bulat dan optimal dalam aspek sosial, pribadi, belajar dan karir.

Terdapat beberapa bidang pengembangan Bimbingan dan Konseling di sekolah yakni, bimbingan Pengembang Pribadi, Sosial, Belajar dan Karir menurut Syafaruddin dkk (2019:82). Yang pertama yakni bimbingan pengembangan pribadi, bimbingan ini diberikan kepada siswa dalam ranah pengembangan pribadi individu. Bimbingan yang diberikan kepada siswa dalam memahami dan menyelesaikan permsalahan pribadi, seperti agar lebih bertaqwa kepada tuhan Yang Maha Esa, mengambil keputusan dalam permasalahan pribadi. Kemudian bimbingan Sosial dalam bidang ini konseli memberi arahan dan masukan kepada siswa terkait permasalahan sosial yang dihadapai siswa. Seperti hubungannya dengan sessama teman, guru dan dalam lingkungan masyarakat. Seperti contohnya guru Bimbingan dan Konseling membantu siswa untuk memahami lingkungan masyarakat, memiliki rasa empati, memahari keragaman sosial budaya sekitar, bertoleransi dan bergaul dangan teman sebaya. Kemudian selanjutnya yakni bidang pengembangan belajar, hal ini sangat berkaitan erat dengan suasana pembelajaran di sekolah serta gaya belajar siswa. Disini guru Bimbingan dan Konseling berperan sebagai pemberi arahann terkait bagaimana siswa dapat memahami potensi yang dimiliki dalam belajar, memahami masalah belajar, motif belajar yang dimiliki dan cara belajar yang efektif sehingga pada akhir pembelajaran siswa dapat dikategoikan dalam kata sukses. Yang terakhir adalah bidang pengembangan karir, pada bidang ini tentu saja berkaitan dengan pekenalan, pemilihan, persiapan, dan akhinya dalah kesuksesan karir siswa menyelesaikan pembelajaran di bangku sekolah. Bimbingan pada bidang karir ini harus diberikan kepada siswa sedini mungkin. Peran guru Bimbingan dan Konseling disini dapat berupa memberikin fasilitas, perkembangan, eksplorasi, aspirasi dalam sepanjang karir siswa. Sehingga siswa dapat memahami mina tbakat yang dimiliki terkait dengan pekerjaan, pemahaman dalam pengetahuan tentang informasi karir dan dunia kerja yang akan menunjang kematangan potensi karir yang dimiliki.

Kemudian seperti yang telah kita ketahui bahwa Indonesia masih berada dalam proses berperang melawan wabah COVID-19 baik sebelum, kemudian sejak ditetapkannya COVID-19 sebagai pandemi oleh $W H O$, hingga saat ini. Adanya wabah COVID-19 memberi pengaruh yang besar terhadap masyarakat dan tatanan pemerintah di Indonesia, pengaruh tersebut berada dalam segala aspek kehidupan masyarakat di Indonesia, dalam asppek Ekonomi, Politik, Agama, Pendidikan dan lainnya. Pengaruh dalam aspek pendidikan adalah dengan diberlakukannya pembelajaran daring. Pembelajaran daring ditetapkan pemerintah setelah diumumkan awal masuknya COVID-19 di Indonesia. Hal tersbut diberlakukan terhadap seluruh jenjang pendidikan di Indonesia baik dari jenjang TK, SD, SMP, SMA hingga perkuliahan. Kebijakan sekolah daring dilakukan kurang lebih selama tiga semester. Menurut Handarini (2020) Pembelajarn daring merupakan pembelajaran yang memanfaatkan teknologi seperti whatsapp, zoom dan platform lainnya, sehingga pembelajaran dapat dilakukan dalam jarak jauh dan tidak memerlukan kegiatan tatap muka atau bertemu

Dipublikasikan Oleh :

UPT Publikasi dan Pengelolaan Jurnal

Universitas Islam Kalimantan Muhammad Arsyad Al-Banjari Banjarmasin 


\section{Farda Muslimah $^{1}$, Imro'atul Hayyu Erfantini ${ }^{2}$ \\ Jurnal Mahasiswa BK An-Nur : Berbeda, Bermakna, Mulia \\ Volume 7 Nomor 2 Tahun 2021 \\ Tersedia Online: https://ojs.uniska-bjm.ac.id/index.php/AN-NUR \\ p-ISSN. 2460-9722 | e-ISSN. 2622-8297}

secara langsung. Akibat diberlakukannya sekolah daring maka hal tersebut menyebaBimbingan dan Konselingan dialihkannya seluruh kegiatan belajar mengajar tanpa harus bertemu secara langsung, termasuk juga dalam aspek Bimbingan dan Konseling. Kegiatan Bimbingan dan Konseling memiliki bidang masing-maing dalam penerapannya pada tingkat kelas siswa yakni pada siswa baru, siswa tingkat dua dan siswa kelas tiga. Salah satu bimbingan kepada siswa yang mnyeluruh adalah bimbingan karir kepada siswa kelas 12 SMA. Siswa sangat perlu bimbingan yang intens, dan berkesinambungan mengingat bimbingan karir adalah bidang yang sangat urgent untuk diberikan kepada siswa. Sedangkan seperti yang telah kita ketahui dalam pembelajaran daring banyak sekali potensi miskomunikasi, keterbatasan media dan hambatan-hambatan lainnya yang mungkin dialami baik siwa maupun guru Bimbingan dan Konseling

Penelitian ini dilakukan untuk mengetahui upaya pelaksanaan bimbingan konseling yang dilakukan oleh guru Bimbingan dan Konseling dalam pengembangan bidang karir yang mana dilakukan kepada siswa kelas XII SMA dalam masa pandemi COVID-19 dengan kondisi sekolah daring. Penelitian ini penting dilakukan untuk mengetahui upaya yang telah dilakukan guru Bimbingan dan Konseling dalam memberi bimbingan karir kepada siswa dan mengetahui respon siswa dalam bimbingan karir tersebut. Maka dari itu peneliti tertarik untuk melakukan penelitian yang berjudul "Upaya Pelayanan Bimbingan Karir Terhadap Siswa MAN 2 LAMONGAN Selama Pandemi COVID-19" sehingga dapat ditarik suatu masalahan yaitu; 1. Apa upaya bimbingan karir yang dilakukan oleh guru Bimbingan dan Konseling terhadap siswa MAN 2 Lamongan selama masa pandemic COVID-19? ; 2. Apa saja kendala yang terjadi dalam proses bimbingan karir selama pasa pandemic COVID-19?

\section{METODE}

Dalam penelitian ini, pendekatan yang dilakukan adalah pendekatan kualitatif deskriptif. Pendekatan kualitatif dipilih agar peneliti dapat meneliti secara mendalam terkait upaya bimbingan karir yang dilakukan oleh guru Bimbingan dan Konseling terhadap siswa MAN 2 Lamongan selama masa pandemic COVID-19. Jenis penelitian ini adalah penelitian studi kasus. Penelitian studi kasus atau Case Study merupakan penelitian yang bersifat terbatas dalam suatu kejadian atau peristiwa yang terjadi di sebuah tempat atau instansi tertentu. Kemudian penelitian ini mencoba untuk menggali secara mendalam dan terperinci dalam mengambil data (Creswell, 2015). Lokasi penelitian ini dilaksanakan di Madrasah Aliyah Negeri (MAN) 2 Lamongan. Dalam pendekatan kualitatif Instrumen penelitian peneliti itu sendiri. Oleh karena itu pengambilan data dilakukan dengan tekhnik Wawancara, wawancara merupakan sebuah kegiatan tanya jawab antar interviewer (pewawancara) dan interviewee (yang di wawancara) untuk membahas suatu permasalahan tertentu yang dilakukan dengan tujuan untuk mengumpulkan informasi (Hardani, dkk,137, 2020). Subject Penelitian adalah Guru Bimbingan dan Konseling MAN 2 Lamongan dan 8 Siswa kelas 12 MAN 2 Lamongan. Subject dipilih secara purposive yakni salah satu guru Bimbingan dan Konseling yang megampu kelas 12 dan siswayang pernah melakukan konsultasi bimbingan karir kepada guru Bimbingan dan Konseling. Siswa dipilih berdasarkan jurusan yang berbeda yakni jurusan MIPA, IPS, AGAMA, dan BAHASA, selanjutnya dipilih 2 siswa tiap jurusan. Hal tersebut dilakukan agar mendapat data keseluruhan dari masing-masing jurusan. Penelitian ini menggukan Model Miles dan Huberma dalam melakukan analisi data. Yang meliputi tiga langkah kerja yaitu reduksi data, penyajian data, dan menarik kesimpulan mnurut Sugiyono (2010). Kredibelitas dan kebenaran data penelitian diuji kualitatif dengan triaggulasi dan member check (Moleong, 2010).

\section{HASIL DAN PEMBAHASAN}

Wawancara dilaksanakan dengan dua metode yaitu metode offline dan online. Wawancara offline dilaksanakan di MAN 2 Lamongan, pada hari Kamis, tanggal 29 Mei 2021. Pada pukul 07.00 WIB. Wawancara dilakukan oleh peneliti dengan subject Pertama yakni salah satu Guru Bimbingan dan Konseling MAN 2 Lamongan yang bernama Sri Utami, S.Pd. Beliau merupakan salah satu dari ke lima guru Bimbingan dan Konseling yang mengajar di MAN 2 Lamongan. Beliau juga mengampu kelas XII dan melayani konsultasi bimbingan karir dengan siswa. Kemudian wawancara yang kedua dilaksanakan dengan metode online memalui media WhatsAps, yang dilaksanakan pada Hari Senin hingga Sabtu pada tanggal 31 Mei 2021 hingga 5 Juni 2021.Wawancara dilakukan oleh peneliti dengan 8 siswa kelas XII MAN 2 Lamongan. Yang mana terdapat 2 siswadalam masing-masing jurusan, yakni jurusan MIPA, IPS, AGAMA dan BAHASA.

Dipublikasikan Oleh : 
Farda Muslimah $^{1}$, Imro'atul Hayyu Erfantini ${ }^{2}$

Jurnal Mahasiswa BK An-Nur : Berbeda, Bermakna, Mulia

Volume 7 Nomor 2 Tahun 2021

Tersedia Online: https://ojs.uniska-bjm.ac.id/index.php/AN-NUR

p-ISSN. 2460-9722 | e-ISSN. 2622-8297

Upaya yang dilakukan oleh guru Bimbingan dan Konseling

Berdasarkan hasil wawancara terdapat beberapa upaya yang telah dilakukan guru Bimbingan dan Konseling, yakni sebagai berikut: (1). Diadakannya Sosialisasi Jalur masuk perguruan tinggi pada awal semester genap; (2). Diadakanya $C C D$ atau Carrier and College Day secara daring; (3). Dibuatnya Grup WhatsAps antara Guru Bimbingan Konseling dan siswa kelas XII sesuai jalur masuk PTN; (4). Diadakannya Sesi Konsultasi secara luring di ruang Bimbingan dan Konseling bagi siswa yang memiliki kendala saat melakukan konsultasi online; (5). Guru Memberikan informasi Lowongan Pekerjaan yang disebarkan melalui grup-grup kelas. Sejalan dengan hasil wawancara yang diperoleh dari 8 siswa terkait upaya bimbingan dan Konseling yang dilakuan di MAN 2 Lamongan. Yang akan diuraikan sebagai berikut;

Didakannya sosialisasi jalur masuk perguruan tinggi pada awal semester genap oleh guru Bimbingan konseling. Berdasarkan informasi data yang telah diperoleh dari 8 siswa kelas XII MAN 2 Lamongan didapati bahwa sosialisasi tersebut dilaksanakan selama 4 hari secara bertahap, Hari pertama membahas PTN (Perguruan Tinggi Negeri) dan PTS (Perguruan Tinggi Swasta). Dari sosialisasi ini siswa bdapat mengetahui perbdaan antar keduanya, menurut narasumber ada beberapa siswa yang sebenarnya belum mengerti perbedaan antar keduanya, dalam segi jalur masuk, biaya pendidikan dan lain-lain. Sehingga setelah diberikan sosialisasi tesebut siswa memiliki pandangan untuk melanjutkan pendidikan baik ke PTN, PTS. Kemudian siswa juga diberi Informasi mengenahi Sekolah Pramugari, Sekolah Kedinasan dan Informasi Beasiswa. Hal tersbut membuat siswa tidak miskin informasi sehingga dapat menunjang karir siswa dengan baik kedepaannya. Kemudian selain itu siswa juga diperssilahkan berkonsultasi pilihan universitas dan jurusan dengan guru Bimbingan dan Konseling. Setelah itu di hari selanjutnya di laksanakan nya sosialisasi megenahi seleksi masuk Perguruan Tinggi Jalur SNMPTN dan SPANPTKIN dalam sosialisasi tersebut siswa diberi arahan mengenahi proses atau sitematika pendaftaran, pengumpulan berkas hingga tahap-tahap selanjutnya. Kemudian hari ketiga yaoiti pemilihan prodi dan Universitas dan pertemuan terakhir daftar ulang saat siswa tellah diterima.

Diadakannya $C C D$ atau Carrier and College Day secara daring melalui platform Zoom Meeting. Kegiatan tersebut dilaksanakan pada hari Rabu, tanggal 13 januari 2021 dalam acara tersebut pihak MAN 2 Lamongan Mengundang perwakilan mahasiswa dari berbagai PTN, PTS, Sekolah Tinggi Pramugari dan Sekolah Kedinasan. Acara tersebut dimulai pada pukul 7.30 WIB dan berakhir hingga pukul 11.30 WIB. Acara tersebut diawali dengan pembukaan dan sembutan kemudian terbagi atas 3 sesi presentasi tiap beberapa Universitas. Setiap perwakilan mahasiswa mempresentasikan mengenahi lingkingan kampus dan kemudian siswa boleh melemparkan beberapa pertanhyaan. Acara tersebut diadakan dengan tujuan untuk memberi wawasan kepada siswa mengenahi perguruan tinggi selain itu siswa juga boleh memberikan pertanyan kepada perwakilan mahasiwa terkait pengalamannya selama mendaftar menjadi mahasiswa hingga diterima di perguruan tinggi.

Dibuatnya Grup WhatsAps antara Guru Bimbingan Konseling dan siswa kelas XII sesuai jalur masuk PTN. Berdasarkan wawancara yang telah dilakukan, ada beberapa grup yang yang telah dibuat oleh guru Bimbingan dan Konseling sebagai learning magagement dan juga sebagai media pertukaran informasi bagi siswa dan guru. Beberapa grup tersebut seperti grup siswa yang mendaftar jalur SNMPTN, grup dengan jalur SPAN-PTKIN, hingga grup jalur mandiri. Alasan dipilihnya grup tersebut sebagai satusatunya media informasi adalah untuk mengantisipasi siswa yang terkena hambatan sinyal apabila mengadak face to face meeting. Karena setelah berjalan beberapa bulan pembelajaran daring, masih saja ada siswa yang mengalami kendala sinyal. Kemudian selain itu grup tersebut juga dijadika sebagai sarana bertukar informasi kepada guru Bimbingan dan Konseking serta siswa. midalnya apabila ada seorang siswa yang memiliki suatu permasalahan, guru bimbingan dan Konseling dapat mengirimpertanyaan tersebut dalam grup juga disertai dengan solusinya, sehingga apabila ada siswa yang mengalami masalah serupa dapat terselaesaikan oleh penjelasan di grup.

Diadakannya Sesi Konsultasi secara luring di ruang Bimbingan dan Konseling bagi siswa yang memiliki kendala saat melakukan konsultasi online. Sesi konsultasi offline ini disediakan oleh guru Bimbingan dan Konseling sebagai antisipasi siswa yang memiliki kendala saat berkonsultasi online seperti Susah sinyal ataupun keterbatasan alat komunikasi. Karna beberapa siswa masih adayang mengalami petrmasalahan tersebut. Pelayanan Bimbingan dan Konseling ini dilakukan di ruang BK dengan sesi tertentu dalam suatu kelas. Selain itu diluar jadwal tersebut siswa juga dapat mengajukan

Dipublikasikan Oleh :

UPT Publikasi dan Pengelolaan Jurnal

Universitas Islam Kalimantan Muhammad Arsyad Al-Banjari Banjarmasin 
Farda Muslimah $^{1}$, Imro'atul Hayyu Erfantini ${ }^{2}$

Jurnal Mahasiswa BK An-Nur : Berbeda, Bermakna, Mulia

Volume 7 Nomor 2 Tahun 2021

Tersedia Online: https://ojs.uniska-bjm.ac.id/index.php/AN-NUR

p-ISSN. 2460-9722 | e-ISSN. 2622-8297

bimbingan dengan caramembuat list konsultasi dengan guru Bimbingan dan Konseling di grup kelas. Pelayanan bimbingan dan konseling ini dilakukan dengan mematuhi protokol kesehatan. Kemudian di ruang Bimbingan dan Konseling juga menyediakan fasilitas komputer yang terhubung dengan koneksi internet yang dapatt dimanfaatkan siswa untukkeperluan mendaftar ke perguruan tinggi. Pelayanan bimbingan secara offline di madrasah dibuka setiap hari, karena setiap hari selalu ada guru bimbingan dan Konseling yang berjaga dan siap membantu siswa.
Guru Memberikan informasi Lowongan Pekerjaan yang disebarkan melalui grup-grup kelas. Tidak hanya memperhatkan mengenahi karir akademik siswa guru bimbingan dan Konseling juga memberikan informasi terkain lowongan perkerjaan, penerimaan karyawan baru dan lain-lain. Berdasarkan hasil wawancara oleh 8 siswa tersebut ada beberapa siswa yang tidak mengetahu adanya lowongan ketrja tersebut, ada siswa yang mengetahui namun tidak membunya karena tidak ada minat bekerja setelah tamat

SMA.

\section{Kendala yang dalami Siswa dan Solusinya}

\begin{tabular}{|c|c|c|c|}
\hline Subject Penelitian & Jurusan & Metode Konsultasi & $\begin{array}{c}\text { Alasan Kendala Yang } \\
\text { Dihadapi }\end{array}$ \\
\hline Siswa 1 & MIPA & Online-Offline & Signal \\
\hline Siswa 2 & MIPA & Online & Tidak Ada \\
\hline Siswa 3 & IPS & Online & Tidak Ada \\
\hline Siswa 4 & IPS & Online & Tidak Ada \\
\hline Siswa 5 & AGAMA & Online-Offline & Penjelasan Kurang Rinci \\
\hline Siswa 6 & AGAMA & Online-Offline & $\begin{array}{l}\text { Banyak Terjadi } \\
\text { Miskomunikasi }\end{array}$ \\
\hline Siswa 7 & BAHASA & Online & Meida Kurang Memadai \\
\hline Siswa 8 & BAHASA & Online & $\begin{array}{c}\text { Pelayanan BK Slow } \\
\text { Response }\end{array}$ \\
\hline
\end{tabular}

Tabel 1.1 Daftar Metode Konsultasi dan Kendala yang dialami siswa selama pandemic COVID-19

Berdasarkan tabel tersebut didapati bahwa selama pandemic COVID-19 ada 2 kategori metode konsultasi yang dilakukan oleh siswa yaitu full online dan onine-offline. Setiap siswa memiliki kapasitas kemampuan yang berbeda-beda dalam melakukan konsultasi tersebut serta kendala masing-masing saat nelakukan konsultasi. Dapat disimpulkan bahwa Siswa 2,3, dan 4 melakukan konsultasi secara online dan tidak terjadi kendala apapun saat melakukan konsultasi, jadi ketiga siswa tersebut hanya melaksanakan konsultasi secara online dan mematuhi arahan guru Bimbingan dan Konseling melalui grupgrup yang telah disediaakan. Selain itu dapat diasumsikan bahwa siswa tersebut tidak memerlukan konsultasi yang intens terhadap rencana dan pelaksanaan meneruskan karir kuliah. Kemudian siswa 7 yang melakukan konsultasi secara online namun memiliki kendala Media yang kurang memadahi yaitu kerusakan handphone. Berdasarkan hasil wawancara yang telah dilakukan, siswa 7 melaksanakan konsultasi secara online saat kondisi handphone dapat berfungsi, kemudian dari pihak guru Bimbingan dan Konseling merespon siswa tersebut dengan baik. Sehingga konsultasi dilakukan dengan baik pula, oleh karena itu pada akhirnya siswa dpat melaksanakan pendaftaran ke perguruan tinggi dengan lancar. Selain itu terdapat siswa 8 yang juga melakukan konsultasi secara online, namun memiliki kendala Pelayanan guru Bimbingan dan Konseling yang slow response. Berdasarkan hasil wawancara yang dilakukan dengan siswa 8 ada waktu-waktu tertentu yang membuat pelayanan guru Bimbingan dan Konseling menjadi slow response. Namun hal tersebut dapat dimaklumi oleh siswa, karena guru Bimbingan dan Konseling pastinya juga mendapat banyak pesan dari siswa lain. Namun setelah guru Bimbingan dan Konseling merespon pesan dari siswa 8, giru Bimbingan dan Konseling menjelaskan dan membei arahan semaksimal mungkin sehingga akhirnya masalah pada siswa dapat terselesaikan.

Kemudian Pelayanan Bimbingan dan Konseling yang dilaksanakan secara Online-offline, pelaksanaan Bimbingan dan Konseling pada metode ini memiliki kendala yang bermacam-macam. Seperti

Dipublikasikan Oleh :

UPT Publikasi dan Pengelolaan Jurnal

Universitas Islam Kalimantan Muhammad Arsyad Al-Banjari Banjarmasin 
Farda Muslimah $^{1}$, Imro'atul Hayyu Erfantini ${ }^{2}$

Jurnal Mahasiswa BK An-Nur : Berbeda, Bermakna, Mulia

Volume 7 Nomor 2 Tahun 2021

Tersedia Online: https://ojs.uniska-bjm.ac.id/index.php/AN-NUR

p-ISSN. 2460-9722 | e-ISSN. 2622-8297

yang terjadi pada Siswa 1 berdasatrkan wawancara yang telah dilakukan, siswa 1 mengalami kendala saat melakukan bimbingan dan konseling karena memiliki kendala sinyal. kemudian solusi dari guru Bimbingan dan Konseling adalah dengan datang kesekolahan dan melakukan konsultasi secara offline di ruang BK. selain itu terdapat pula kendala yang dialami oleh Siswa 5 yaitu penjelasan kurang rinci, berdasarkan wawancara yang telah dilakukan dengan narasumber, saat siswa melakukan konsultasi dengan guru Bimbingan dan Konseling, siswa mendapati bahwa penjalasan dari guru Bimbingan dan Konseling kurang rinci sehingga siwa masih merasakan kebingungan. Kemudian pada akhirnya guru Bimbingan dan Konseling menyarankan agar siswa datang ke ruang BK untuk melakukan konsultasi offline. Sama halnya degan yang dialami oleh Siswa 6, berdasarkan hasil wawancara yang telah diperoleh, siwa juga mengalami kebingungan karenasering terjadi miskomunikasi saat melangsungkan konsultasi online dan akhirnya sam dengan teman-temannya yang lain akhirnya solusi dari permasalahan tersebut akhirnya siswa membuat jadwal konultasi offline yang dilakukan d sekolah dan membagikannya dalam grup WhatsAps. Pelayanan Konsultasi Bimbingan dan Konseling yang dilakukan di sekolah selalu mematuhi protocol kesehatan seperti pengecekan suhu, memakai masker, selalu cuci tangan bahkan di dalam ruang BK juga terdapat handsanitizer yang dapat dimanfaatkan digunakan oleh siswa. Kemudian untuk mengantisipasi terjadinya kerumunan guru Bimbingan dan Konseling selalu menjadwalakan konsultasi dengan siswa yang mana telah disebarkan dalam grup.Dalam pelasanaan konsultasi, tiap sesi nya dibatasi 3 anak dalam satu ruangan.

\section{PENUTUP}

Berdasarkan hasil penelitian yang telah dilakukan di MAN 2 Lamongan tentang upaya pelayanan bimbingan karir terhadap siswa kelas XII dapat diambil kesimpulan yaitu upaya yang teah dilakukan guru Bimbingan dan Konseling antara lain: (1). Diadakannya Sosialisasi Jalur masuk perguruan tinggi pada awal semester genap; (2). Diadakanya $C C D$ atau Carrier and College Day secara daring; (3). Dibuatnya Grup WhatsAps antara Guru Bimbingan Konseling dan siswa kelas XII sesuai jalur masuk PTN; (4). Diadakannya Sesi Konsultasi secara luring di ruang Bimbingan dan Konseling bagi siswa yang memiliki kendala saat melakukan konsultasi online; (5). Guru Memberikan informasi Lowongan Pekerjaan yang disebarkan melalui grup-grup kelas. Kemudian Kendala yang dihadapi saat pelaksanaan konsultasi
Online adalah Sinyal yang tidak memadahi, kedala media yang kurang menadahi, Tidak terjadi komunikasi yang sempurna antara Siswa dan Guru Bimbingan Konseling, dan ketertabasan waktu dan kesempatan gruru Bimbingan dan Konseling dalam melayani konsultasi dengan siswa. Namun hal tersebu diatasi dengan penyediaan konsultasi offline dengan mematuhi protokol kesehatan.

\section{Saran}

Saran terhadap guru Bimbingan dan Konseling, sudah selayaknya menjadi tanggung jawab guru Bimbingan dan Konseling sebagai fasilitator dan pemberi masukan serta pemahaman bimbingan karir kepada siswa. Karena sejatinya siswa memang masih butuh bimbingan dan dampingan Guru Bimbingan dan Konseling Saran terhadap orang tua selayaknya orang tua juga harus ikut andil terhadap peilihan keputusan karir siswa. Karena siswa mjuga sangat membutuhkan dukungan dan doronga dari orang tua. Sebaliknya orang tua juga tidak boleh memaksakan kehendak siswa karena karir seorang anak harus sejalan dengan minat yang dimiliki.

\section{REFERENSI}

Hermawan dkk (2019). Strategi Layanan Bimbingan dan Konseling Untuk Meningkatkan Harga Diri Siswa: Sebuah Studi Pustaka. Jurnal Bimbingan Konseling Indonesia. Volume 4 Nomor 2 Bulan September 2019. Halaman 6569 p-ISSN: 2477-5916 e-ISSN: 2477-837

Syafaruddin dkk (2019). Dasar-Dasar Bimbingan dan Konseling Telaah Konsep, Teori dan Praktik. Medan: Perdana Publishing

Handarini, Oktafia Ika. (2020). Pembelajaran Daring Sebagai Upaya Study From Home (SFH) Selama Pandemi Covid 19. Jurnal Pendidikan Administrasi Perkantoran (JPAP). Volume 8, Nomor 3, 2020 hal 496-503

Creswell, J. W. (2015). Penelitian Kualitatif \& Desain Riset. Yogyakarta: Pustaka Pelajar

Hardani dkk.(2020). Metode Penelitian Kualitatif dan Kuantitatif. Yogyakarta: Penerbit CV Pustaka Ilmu

Moleong. (2010). Metode Penelitian Kualitatif. Bandung: PT. Remaja Rosdakarya.

Sugiyono. (2010). Metode Penelitian Pendidikan. Bandung: Alfabeta

Dipublikasikan Oleh : 